\title{
Czy u kobiet obarczonych wysokim ryzykiem raka piersi należy wykonywać profilaktyczną mastektomię? Głos na TAK
}

\author{
Arkadiusz Jeziorski
}

\section{Prophylactic mastectomy should be used in high risk breast cancer patients}

Predyspozycje genetyczne wykazuje około 30\% chorych na raka piersi. Klinicznie ujawniają się jako zespoły tzw. dziedzicznego raka piersi (hereditary breast cancer - site specific — HBC-ss), dziedzicznego raka piersi i jajnika (hereditary breast-ovarian cancer - HBOC) oraz dziedzicznego raka jajnika swoistego narządowo (hereditary ovarian cancer - HOC). W zespole HBC-ss u członków rodzin występują raki piersi, a nie stwierdza się raków jajnika; w zespole HBOC wśród krewnych rozpoznawane są zarówno raki piersi, jak i jajnika, zaś w zespole HOC w rodzinach występują raki jajnika, natomiast nie stwierdza się raków piersi [1].

Corocznie w Polsce na dziedziczne raki piersi zapada ok. 1800 kobiet $w$ wieku ponad 40 lat, $w$ tym ok. 300 na raki BRCA1-zależne oraz ok. 750 kobiet (w wieku średnio nieco ponad 50 lat) — na dziedziczne raki jajnika, w tym ok. 450 na raki BRCA1-zależne [2]. Dziedziczne raki można wykrywać dzięki zastosowaniu specjalistycznego, odmiennego od standardowego, systemu badań kontrolnych, co pozwala zapobiec znacznemu odsetkowi zachorowań. Warunkiem właściwego postępowania lekarskiego w stosunku do kobiety z guzem piersi, u której podejrzewamy raka dziedzicznego, jest wykonanie testu BRCA1/2 jako jednego z pierwszych elementów diagnostyki.

\section{Opis przypadku}

Kobieta, lat 66, zgłosiła się do poradni onkologicznej z powodu mastalgii. W wywiadzie - rak piersi w rodzinie przed 40 rokiem życia. W badaniu klinicznym: piersi mastopatyczne, w prawej piersi wyczuwalne zagęszczenie tkanki gruczołowej, wymagające dalszej diagnostyki. Wynik mammografii - BIRADS „0", USG piersi - wynik niemiaro- dajny, niewnoszący niczego nowego do diagnostyki, BAC - komórki nabłonkowe bez cech atypii. Zaproponowano usunięcie wyczuwalnej zmiany — opis mikroskopowy: Choroba proliferacyjna piersi - liczne brodawczaki i rozrosty brodawczakowate przewodowe, ogniska gruczolistości, rozrosty typu columnar cell hyperplasia, obecne przewody $z$ rozrostem przewodowym atypowym. Zaproponowano poszerzenie zakresu wycięcia, czyli badanie marginesów tkanki gruczołowej piersi po usunięciu wyczuwalnej zmiany: opis mikroskopowy - Choroba proliferacyjna piersi-liczne brodawczaki i rozrosty brodawczakowate przewodowe, ogniska gruczolistości, obecne skupienia przewodów z rozrostem przewodowym atypowym (P63+, aktyna m.gładkich+, CK5/6-, CK34BE12-, rozrosty sitowate).

Czy ta pacjentka kwalifikuje się do profilaktycznej mastektomii? Zapytałem o to kilku polskich onkologów, specjalistów z różnych dziedzin onkologii. Nie byłem zaskoczony, słysząc odpowiedzi skrajne: od obserwacji — do profilaktycznej mastektomii.

\section{Zalecenia}

Różnorodność propozycji postępowania u przedstawionej pacjentki wynika z faktu, że w polskiej literaturze onkologicznej nie było — jak dotąd — merytorycznej dyskusji na temat metod zapobiegania rakowi piersi, czyli profilaktyki pierwszego rzędu. Pierwsze propozycje profilaktycznej mastektomii jako metody profilaktycznej w polskiej literaturze medycznej pojawiły się w opracowaniach dotyczących dziedziczenia w nowotworach złośliwych [3]. Autorzy przedstawiają w niej metody naturalne, takie jak wczesne urodzenie dziecka czy długotrwałe karmienie piersią, chemoprewencję

\section{Klinika Chirurgii Onkologicznej \\ Uniwersytet Medyczny w Lodzi}

Wystąpienie podczas II Konferencji Naukowej czasopisma Nowotwory „Debaty onkologiczne” 11-12 kwietnia 2014 roku 
czy adneksektomię. Ale zwracają uwagę na to, że mastektomia jest metodą dającą najlepsze efekty, choć nie jest metodą eliminującą ryzyko całkowicie.

Pierwsze próby podania wskazań do profilaktycznej mastektomii w polskim piśmiennictwie pojawiają się w praktycznym przewodniku z 2009 roku, poświęconym rakowi piersi. W rozdziale dotyczącym chirurgicznego leczenia autorzy uznają, że wszelkie wskazania do tej operacji są wskazaniami względnymi. Jednocześnie, mając świadomość niepełnej jego skuteczności, proponują określenie: amputacja redukująca ryzyko zachorowania.

W zaleceniach postępowania diagnostyczno-terapeutycznego w nowotworach złośliwych z 2013 roku problem profilaktyki raka piersi znajduje szersze ujęcie [4]. Pojawiają się propozycje utworzenia dwóch grup ryzyka zachorowania (grupa wysokiego i grupa bardzo wysokiego ryzyka zachorowania) wraz z sugestiami co do wdrożenia pierwotnej profilaktyki, w tym do profilaktycznej amputacji piersi. Przed podjęciem decyzji o zaproponowaniu pacjentce zabiegu profilaktycznej mastektomii należy sprecyzować sposób określenia ryzyka zachorowania: zebrać wywiad rodzinny, przeprowadzić badania genetyczne. Podejmując decyzję o tak rozległej operacji, w oparciu o wiek i obecność chorób współistniejących, należy ocenić przewidywany czas przeżycia, uwzględnić uprzednie leczenie innych nowotworów z przebytym napromienianiem śródpiersia oraz uwzględnić przebyte łagodne choroby piersi przebiegające z proliferacją, szczególnie te $z$ atypią komórkową.

Liczba prac na temat profilaktyki raka piersi w piśmiennictwie światowym jest coraz większa. Autorzy zwracają uwagę na zwiększającą się liczbę wykonywanych profilaktycznych mastektomii w Stanach Zjednoczonych: w latach 1993-2003 wśród chorych z naciekającym rakiem jednej piersi liczba tych zabiegów wzrosła z 1,8\% do 4,5\% (wzrost o 150\%) [5], co — przekładając na liczby bezwzględne — daje rocznie niemal 10 tysięcy kobiet $z$ rakiem piersi operowanych profilaktycznie. Operacje profilaktyczne dotyczą także nosicielek mutacji BRCA, którym wykonuje się amputację obustronną [6, 7].Zabiegowi poddają się z reguły chore młode [8], jako że młody wiek chorych może również wskazywać na tło dziedziczne choroby i przez to większe prawdopodobieństwo zachorowania na raka przeciwległej piersi. Wobec tego pojawiają się propozycje stosowania różnych operacji plastycznych [9]. Autorzy podkreślają fakt, że liczba kobiet poddających się zabiegowi zwiększa się, mimo że nastąpił postęp w stosowaniu metod zachowawczych, takich jak chemoprewencja czy leczenie hormonalne [10]. Wiele prac donosi o wysokiej skuteczności profilaktycznej mastektomii, sięgającej od 91\% [11] do 95\% [12] redukcji ryzyka choroby w drugiej piersi. Ale ciekawą obserwacją jest to, że mimo iż operacja redukuje ryzyko nawrotu choroby to nie ma wpływu na przeżycia całkowite [13-15]. Nie zaleca się wykonywania biopsji węzła wartowniczego w czasie profilaktycznej mastektomii [16]. Przedmiotem rozważań i kontrowersji są także efekty ekonomiczne tego zabiegu [17-19].

\section{Uwagi końcowe}

Obustronna profilaktyczna mastektomia u nosicielek mutacji BRCA1/2 zdecydowanie zmniejsza ryzyko zachorowania na raka piersi w ciągu całego życia. Ryzyko zachorowania na raka piersi, pomimo obustronnej profilaktycznej mastektomii - nadal istnieje. Dlatego operacja profilaktyczna nie gwarantuje uniknięcia zachorowania. Należy uzgodnić sposób uzyskiwania zgody kobiety na zabieg. Zgoda powinna być wieloetapowa i powinna uwzględniać opinię chirurga onkologa, chirurga plastyka, psychologa oraz — w razie potrzeby — innych specjalistów [20].

Operacja ta ma już swoje miejsce w zaleceniach postępowania w przypadku raka piersi, choć, jak sądzę, dyskusja na jej temat w polskiej literaturze medycznej jest niezbędna.

\section{Prof. dr hab. med. Arkadiusz Jeziorski}

Klinika Chirurgii Onkologicznej

Uniwersytet Medyczny w Łodzi

ul. Paderewskiego 4, 93-509 Łódź

e-mail:jeziorski@post.pl

\section{Piśmiennictwo}

1. Lubiński J (red). Nowotwory dziedziczne 2002 — Profilaktyka, diagnostyka, leczenie. Poznań: Termedia, 2003.

2. Lubiński J, Kładny J. Genetyka kliniczne nowotworów. W: Chirurgia Onkologiczna, red. Jeziorski A, Szawłowski A, Towpik E. Tom 1. Warszawa: PZWL, 2010.

3. Jeziorski A, Jaśkiewicz J. Rak piersi. W: Leczenie chirurgiczne. Jassem J, Krzakowski M (red). Gdańsk: Via Medica, 2009.

4. Jassem J, Krzakowski M, Bobek-Billewicz Bi wsp. Rak piersi. W:Zalecenia postępowania diagnostyczno-leczniczego. Gdańsk: Via Medica, 2013.

5. Tuttle TM, Habermann EB, Grund EH i wsp. Increasing use of contralateral prophylactic mastectomy for breast cancer patients: a trend toward more aggressive surgical treatment. J Clin Oncol 2007; 25: 5203-5209.

6. Hartmann LC, Schaid DJ, Woods JE. Efficacy of bilateral prophylactic mastectomy in women with a family history of breast cancer. N Eng J Med 1999; 340: 77-84.

7. Rebbeck TR, Freibel T, Lynch HT. Bilateral prophylactic mastectomy reduces breast cancer risk in BRCA1 and BRCA2 mutation carriers: the PROSE Study Group. J Clin Oncol 2004; 22: 1055-1062.

8. Jones NB, Wilson J, Kotur i wsp. Contralateral prophylactic mastectomy for unilateral breast cancer: an increasing trend at a single institution. Ann Surg Oncol 2009; 16: 2691-2696.

9. Reynolds C, Davidson JA, Lindor NM i wsp. Prophylactic and therapeutic mastectomy in BRCA mutation carriers: can the nipple be preserved? Ann Surg Oncol 2011; 18: 3102-3109.

10. Smith $\mathrm{KL}$, Isaacs C. BRCA mutation testing in determining breast cance therapy. Cancer J 2011; 17: 492-499.

11. Boughey JC, Hoskin TL, Degnim AC. Contralateral prophylactic mastectomy is associated with a survival advantage in high-risk women with a personal history of breast cancer. Ann Surg Oncol 2010; 17: 2702-2709.

12. Van Sprundel TC, Schmidt MK, Rookus MA. Risk reduction of contralateral breast cancer and survival after contralateral prophylactic mastectomy in BRCA1 or BRCA2 mutation carriers. Br J Cancer 2005; 93: 287-292.

13. Herrinton LJ, Barlow WE, Yu O i wsp. Efficacy of prophylactic mastectomy in women with unilateral breast cancer: A cancer research network project. J Clin Oncol 2005; 23: 4275-4286.

14. Peralta EA, Ellenhorn JD, Wagman LD i wsp. Contralateral prophylactic mastectomy improves the outcome of selected patients undergoing mastectomy for breast cancer. Am J Surg 2000; 180: 439-445. 
15. Yao K, Winchester DJ, Czechuta T i wsp. Contralateral prophylactic mastectomy and survival: report from the National Cancer Data Base, 1998-2002. Breast Cancer Res Treat 2013; 142: 465-476.

16. Zhou WB, Liu XA, Dai JC i wsp. Meta-analysis of sentinel lymph node biopsy at the time of prophylactic mastectomy of the breast. Can J Surg 2011; 54: 300-306.

17. Anderson K, Jacobson JS, Heitjan DF i wsp. Cost-effectiveness of preventive strategies for women with a BRCA1 or BRCA2 mutation. Ann Intern Med 2006; 144: 397-406.
18. Norum J, Hagen Al, Maehle L. Prophylactic bilateral salpingo-oophorectomy (BPSO) with or without prophylactic bilateral mastectomy or no intervention in BRCA1 mutation carriers: A cost-effectiveness analysis. Eur J Cancer 2008; 44: 963-971.

19. Brewster AM, Parker PA. Current knowledge on contralateral prophylactic mastectomy among women with sporadic breast cancer. The Oncologist 2011; 16: 935-941.

20. Pruthi S, Gostout BS, Lindor NM. Identification and management of women with BRCA mutations or hereditary predisposition for breast and ovarian cancer. Mayo Clin Proc 2010; 85: 1111-1120. 